\title{
Temperature dependent studies on nutritional, total polyphenols, flavonoids content and antioxidant activities of Aframomum citratum (C.Pereira) K.Schum and Tetrapleura tetraptera (Schum. \& Thonn.) Taub. fruits
}

\author{
Manga Eyenga ${ }^{(1)}$, J. Fotso Youovop ${ }^{(2)}$, J. L. Ngondi ${ }^{(2)}$, M. Sindic ${ }^{(1)}$ \\ (1) Liege University - Gembloux Agro-Bio Tech. Laboratory of Quality and Safety of Agro-food Products. TERRA Research \\ Center. BE-5030 Gembloux (Belgium).E-mail: eyengamanga@doct.uliege.be, emanga2013@yahoo.fr \\ (2) Yaoundé 1 University. Faculty of Sciences. Biochemistry department. Laboratory of Nutrition and Nutritional \\ Biochemistry. Yaoundé (Cameroon).
}

Received 19 October 2019, accepted 10 June 2020, available online 2 July 2020.

This article is distributed under the terms and conditions of the CC-BY License (http://creativecommons.org/licenses/by/4.0)

Description. Hard shelled fruits, Tetrapleura tetraptera and Aframomum citratum nonwood forest products are used as spices and for many medicinal recipes. Mostly used together, they undergo heat treatment before being milled when cooking Mbongo Tchobi, a black spicy stew from central and coastal regions in Cameroon.

Objectives. Evaluate the impact of roasting these spices on the physicochemical properties (dry matter, ash, raw protein, total sugar, raw fibre, $\mathrm{pH}, a_{w}$, total energy, total fat), phytochemical content (total polyphenol, total flavonoids) and the antioxidant activities (total antioxidant activity, FRAP, DPPH and lipid peroxidation inhibition assays) of their aqueous extracts in a home food consumption context.

Method. Tetrapleura tetraptera and Aframomum citratum fruits from Ngola locality in Yokadouma (east region in Cameroon) locality were collected, sorted, cleaned and dried $\left(72 \mathrm{~h}, 45^{\circ} \mathrm{C}\right)$ in an oven. Cut into small pieces, a part was heated using roasting parameters deduced from preliminary tests $\left(140{ }^{\circ} \mathrm{C} / 10 \mathrm{~min} ; 180^{\circ} \mathrm{C} / 20 \mathrm{~min}\right.$ and $150{ }^{\circ} \mathrm{C} / 12 \mathrm{~min}$ respectively for T. tetraptera, A.citratum and a formulation $95 / 5$ of the two spices). The heated and unheated spices were ground and an infusion was prepared from boiling water in the proportion of $1 / 5\left(\mathrm{~g} \cdot \mathrm{ml}^{-1}\right)$ for both types of spices. Physicochemical and phytochemical characteristics (dry matter, total ash, fat, sugar, crude fibre and energy contents, $\mathrm{pH}, a_{w}$, total flavonoids and polyphenols) as well as the antioxidant activities of the aqueous extracts of the two spices and a mix of the two spices were evaluated before and after the heat treatment.

Results. Heat treatment significantly $(p<0.05)$ reduces fat and total sugars contents but improves raw fiber contents for all spices. Phenolic content is more important for heated spices and percentage differences before and after heat treatment are between 8.0 and $23.2 \%$ for both spices. Extracts obtained with heated spices possess the best antioxidant potential. Strong significant positive correlations have been established between the phenolic compounds and the reductive antioxidant activities and negative correlations with the antiradical antioxidant activities as they are expressed as $\mathrm{IC}_{50}\left(\mathrm{mg} \cdot \mathrm{ml}^{-1}\right)$.

Conclusions. In most of the features studied, the heated formulation (95/5) possesses the highest characteristics studied. The choice of heating these spices under the roasting parameters identified should be guided by the desire of improving their antioxidant potential because of the nutritional losses observed after heat treatment.

Keywords. Roasting, phenolic compounds, nonwood forest products, spices, antioxidants.

Influence de la température sur le contenu nutritionnel, les polyphénols et flavonoïdes totaux et les activités antioxydantes des fruits d'Aframomum citratum (C.Pereira) K.Schum et Tetrapleura tetraptera (Schum. \& Thonn.) Taub.

Description du sujet. Considérés comme fruits à coque dure, Tetrapleura tetraptera et Aframomum citratum, produits forestiers non ligneux, sont utilisés comme épices et dans de nombreuses recettes de la pharmacopée traditionnelle. Généralement incorporés ensemble, ils subissent un traitement thermique avant d'être broyés lors de la préparation de la recette du Mbongo Tchobi, sauce noire épicée originaire des régions du Centre et du Littoral au Cameroun. 
Objectifs. Étudier l'impact de la torréfaction sur les propriétés physico-chimiques (matière sèche, cendres, protéines brutes, sucres totaux, fibres brutes, $\mathrm{pH}, a_{w}$, énergie totale, matières grasses totales), les teneurs en polyphénols, les flavonoïdes totaux des deux épices et les activités antioxydantes (capacité antioxydante totale, les tests FRAP, DPPH et d'inhibition de la peroxydation lipidique) de leurs extraits aqueux.

Méthode. Des épices de T. tetraptera et A. citratum provenant de la zone de Ngola à Yokadouma à l'est du Cameroun ont été prélevées, nettoyées et séchées $\left(72 \mathrm{~h}, 45^{\circ} \mathrm{C}\right)$ à l'étuve. Découpées en morceaux, une partie a été chauffée suivant les paramètres de torréfaction déduits de tests préliminaires $\left(140{ }^{\circ} \mathrm{C} / 10 \mathrm{~min} ; 180{ }^{\circ} \mathrm{C} / 20 \mathrm{~min}\right.$ et $150{ }^{\circ} \mathrm{C} / 12 \mathrm{~min}$ respectivement pour T. tetraptera, A. citratum et la formulation $95 / 5$ des deux épices). Les épices chauffées et non chauffées ont été moulues et une infusion (10 min) a été préparée à partir de l'eau bouillante dans la proportion $1 / 5\left(\mathrm{~g} \cdot \mathrm{ml}^{-1}\right)$ pour les trois types d'épices. Des caractéristiques physicochimiques et phytochimiques (matière sèche, cendre totale, matière grasse, sucres totaux, fibres brutes, énergie totale, $\mathrm{pH}, a_{w}$, flavonoïdes totaux, polyphénols totaux) ainsi que l'activité antioxydante des extraits aqueux des deux épices et d'une formulation des deux épices ont été évalués.

Résultats. Le traitement thermique réduit significativement $(p<0,05)$ la teneur en matières grasses et en sucres totaux mais améliore la teneur en fibres brutes de toutes les épices. La teneur en polyphénols totaux et en flavonoïdes totaux est plus importante dans les épices chauffées et les pourcentages de variation avant et après traitement thermique sont compris entre 8,0 et $23,2 \%$. Les extraits obtenus avec des épices chauffées possèdent le meilleur potentiel antioxydant. De fortes corrélations positives et significatives sont établies entre les composés phénoliques et les activités antioxydantes réductrices. Cependant, il existe des corrélations négatives entre les composés phénoliques et les activités antiradicalaires des extraits d'épices car elles sont exprimées en $\mathrm{IC}_{50}\left(\mathrm{mg} \cdot \mathrm{ml}^{-1}\right)$.

Conclusions. La formulation 95/5 traitée thermiquement présente le meilleur potentiel par rapport aux caractéristiques étudiées. Le choix de torréfier ces épices en fonction des paramètres identifiés ci-dessus doit se faire dans le souci d'améliorer leur capacité antioxydante à cause des pertes nutritionnelles enregistrées pendant le traitement thermique.

Mots-clés. Torréfaction, composés phénoliques, produits forestiers non ligneux, épices, antioxydants.

\section{INTRODUCTION}

Culinary habits in most areas in Cameroon use several nonwood forest products such as spices in many traditional dishes. Among the most used (Sneyd, 2013) are Tetrapleura tetraptera (Schum. \& Thonn.) Thaub. and Aframomum citratum (C.Pereira) K.Schum fruits (Figure 1). Tetrapleura tetraptera belongs to the class of Magnoliopsida, the family of LeguminosaeMimosaceae, and is native to the West African rainforest belt. Aframomum citratum is endemic to the tropical flora of sub-saharan Africa and Madagascar and is part of angiosperms, class of Liliopsida, family of Zingiberaceae. Indeed, they are plants from tropical Africa, perennial and aromatic, which spread in the undergrowth of dense humid forests and on the islands

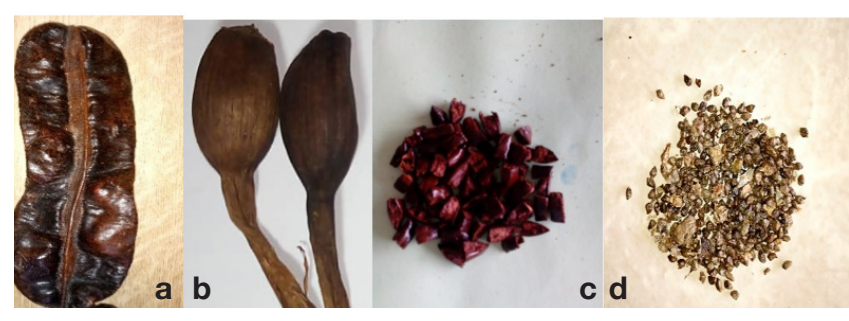

Figure 1.Tetrapleura tetraptera (a) and Aframomum citratum (b) fruits and sliced spices $(\mathbf{c}, \mathbf{d})$ ready to be roasted - Les fruits de Tetrapleura tetraptera (a) et Aframomum citratum (b) entiers et découpés $(\boldsymbol{c}, \boldsymbol{d})$ pour la torréfaction. of the Gulf of Guinea. In Cameroon (Eyog-Matig et al., 2006), these species are found in the Centre, South, East, Littoral, Southwest and West regions (rainy secondary forests, wooded savannahs, plains or semi-deciduous forests).

The use of these spices, although varying from one region to another, requires a prior stage of heat treatment, either in the frying pan (on low heat) or on embers (high heat), before the milling stage (Njike Nya, 1998; Ngo Samnick et al., 2016) especially in Littoral and West regions. The most popular dishes are mbongo tchobi (black stew with fish or meat), yellow soup, and pepe soup (meat or fish broth). Mbongo tchobi from the Littoral region is made with roasted spices (Immaculate Bites, 2013), which are used to bring out specific aromas and the stew's black color, the main characteristics of this traditional meal. Among the spices used in those recipes, T.tetraptera and $A$. citratum fruits are generally mixed together as ingredients. However, heat treatment in the production and processing has several consequences, such as: aroma release, the development of specific tastes, color modification, the reduction or destruction of microbial flora, the destruction of anti-nutritional factors, the inactivation of enzymes, prolongation of the shelf life of food products, modification of their chemical composition and the bioavailability of food constituents (Maskat \& Tan, 2011). Horváthová et al. (2007) reported that heat treatment causes changes in the integrity of the plant's cell structure, which would 
lead to positive and/or negative effects on the antioxidant activity of its constituents. As an illustration, increasing treatment temperature and time caused an increase in antioxidant activity, brown pigment formation (BPF) and total polyphenols (TPC) content of Iranian jujube honey heated at various temperatures $(45,55$ and $65^{\circ} \mathrm{C}$ ) over 10 days according to Mohammad et al. (2019). This increase was more pronounced in samples heated to $65^{\circ} \mathrm{C}$ rather than those heated to 45 or $55^{\circ} \mathrm{C}$, which indicates a high dependence of the antioxidant activity, BPF and TPC on the time and temperature of heating. Conferring to Jongen (2002), thermal treatments of tomato have caused an increase in the bioavailability of lycopene and total antioxidant activity. Nikousaleh \& Prakash (2016) have also shown that the antioxidant components and properties of clove (Syzygium aromaticum L.) Merr. \& L.M.Perry are improved following medium flame roasting on a thick frying pan for $5 \mathrm{~min}$ and in a microwave oven for $2 \mathrm{~min}$. Conversely, a very high temperature $\left(250^{\circ} \mathrm{C}\right)$ caused a decrease of chlorogenic acid amount and antioxidant activity on eggplant (Solanum melongena L.) samples according to Silarova et al. (2019).

Turmeric (Curcuma longa L.) and ginger (Zingiber officinale Roscoe) heated for $1 \mathrm{~h}$ at $120^{\circ} \mathrm{C}$ (Vankar et al., 2006) also show opposite results. Indeed, ginger showed a reduction in antioxidant capacity following the heat treatment, unlike turmeric.

Tumuluru (2016) reports that the thermal pretreatment regimes are divided into three zones: non-reactive $50-150{ }^{\circ} \mathrm{C}$, reactive $150-200{ }^{\circ} \mathrm{C}$, and destructive drying $200-300^{\circ} \mathrm{C}$. It is clear that the useful nutritional and functional properties of food are modified after heat treatment. Based on scientific reports by several authors (Yashin et al., 2017), due to their active ingredients, spices and aromatic herbs possess technological, nutritional and therapeutic potential, which are useful for the prevention and the accompaniment of many diseases (cardiovascular diseases, arthritis, coughs, diabetes, etc.). In 2013, Nwaichi \& Anyanwu heat-treated T.tetraptera spices using the temperature range of 60 to $80^{\circ} \mathrm{C}$. At present, the changes that occur during the roasting of those two spices at temperatures above $100{ }^{\circ} \mathrm{C}$ are unknown since they undergo variable processes using heat before ingestion. Therefore, our objectives are to cast light on the various nutritional, phytochemical, physical and biological changes inside the spices during heat treatment. For an innovative investigation, heat treatment under the non-reactive thermal regime has been applied in order to appreciate the various culinary modes or remedy preparations using the two spices in the context of home food consumption. Our investigation can be useful for consumers as the efficiency and health effects of those spices depend on the quantity of nutrients ingested and their effective bioavailability.

\section{MATERIALS AND METHODS}

\subsection{Plant materials}

Aframomum citratum and $T$. tetraptera fruits were harvested from Ngola $\left(3^{\circ} 35^{\prime} 57.3061^{\prime} \mathrm{N}\right.$, $15^{\circ} 5^{\prime} 52.7986^{\prime}$ 'E) in Yokadouma (chief town of Boumba and Ngoko division in East region - Cameroon). Each specimen was identified by Dr Fongnzossie Evariste, botanist at Douala University, and voucher specimens ( ${ }^{\circ} 31610 / \mathrm{NHC}, \mathrm{N}^{\circ} 37795 / \mathrm{NHC}$ respectively) were deposited in the National Herbarium for further reference. Samples were sorted, cleaned and subsequently dried $\left(45^{\circ} \mathrm{C} / 3\right.$ days $)$ using an oven, and then kept for further analysis under a controlled atmosphere.

\subsection{Heat treatment and preliminary studies}

Dried spices were sliced into small equal pieces (Figure 1) and roasted using a home coffee roaster machine (Vingloo, 1200 w; 110/220 V). Roasting temperatures and times were chosen according to previous tests on polyphenol extraction optimization. Initially, the roasting parameters were selected by preliminary experiments on the basis of single factor multiple levels. During this experience, spices were heated at 100,120,140,160,180, 200, 220 and $240{ }^{\circ} \mathrm{C}$ at a fix roasting time $(15 \mathrm{~min})$ to identify the optimal temperature for the total polyphenols recovery. Roasting times of $0,5,10,15,20,25,30 \mathrm{~min}$ at a fixed roasting temperature of $140{ }^{\circ} \mathrm{C}$ (identified as the temperature with the maximum total polyphenols recovery) was applied in other to identify the roasting time corresponding to the highest total polyphenols recovery. At the end of these preliminary assays, roasting parameters of both spices and the formulation were fixed.

Four formulations between T.tetraptera and A. citratum were performed in the various proportions $95 / 5,90 / 10,85 / 15,80 / 20(\mathrm{w} / \mathrm{w})$ in order to keep the formulation with the highest phenolic content.

After heat treatment, the spices were cooled at room temperature before crushing. Resulting powders were then vacuum bagged and kept at $4{ }^{\circ} \mathrm{C}$ for further analysis.

\subsection{Plant extract preparation}

Extracts were prepared in a home food consumption context. Water was used as solvent (even if it is not the best solvent for phenolic compounds extraction) for the various extractions because of its safety and the absence of non-harmful effect for human consumption. Practically, $1 \mathrm{~g}$ of plant material powder (raw/heated according to the test) was introduced into a conical tube 
for extraction and boiled distilled water $\left(100{ }^{\circ} \mathrm{C}\right)$ was added according to the extraction ratio (1/5: weight/ volume). After mixing, a brewing time of $10 \mathrm{~min}$ at room temperature was observed. Then, the tubes were cooled and centrifuged and the collected supernatant was freeze-dried. The dried extracts were vacuum bagged and kept at $-18{ }^{\circ} \mathrm{C}$.

\subsection{Physicochemical analysis}

Dry matter, ash, total fats, raw proteins, total sugars and raw fibre content determination. The method used for dry matter, ash and fatty acids determination was the one published by Nwinuka et al. (2005).

Concerning dry matter determination, thermal drying method was used in the determination of moisture content of the samples. One gram of dried sample was weighed in triplicate and was placed in an oven and dried at $105^{\circ} \mathrm{C}$ until the weight remains constant. The dry matter content was subtracted to the percentage moisture content (MC) calculated as follows:

$$
M C(\%)=\frac{W 2}{W 1} \times 100
$$

where $W 2=$ loss in weight $(\mathrm{g})$ on drying and $W 1=$ initial weight of sample $(\mathrm{g})$.

For the ash content determination, $1 \mathrm{~g}$ of the oven-dried sample used in moisture determination was weighed in triplicate and placed in the pre-heated, cooled and weighed crucible and then reweighed. The crucible was placed in a cold muffle furnace. The temperature was allowed to rise up to $500{ }^{\circ} \mathrm{C}$ and the ashing carried on for $3 \mathrm{~h}$. The crucible was removed from the furnace, allowed to cool in a desiccator, and reweighed. The percentage ash content was calculated using the formula:

$$
\operatorname{Ash}(\%)=\frac{M a}{M s} \times 100
$$

where $M a=$ mass of ash ( $\mathrm{g})$ and $M s=$ mass of sample used $(\mathrm{g})$.

Crude fat content of the samples was done using Soxhlet type of the direct solvent extraction method. Three of the dried samples were weighed in triplicate and secured in Soxhlet extraction thimble. The thimble was then put into $20 \mathrm{~cm}^{3}$ capacity Soxhlet extractor. A washed, oven-dried round-bottomed flask was weighed and approximately $60 \mathrm{~cm}^{3}$ of petroleum ether added to it. The flask was then mounted and connected to the extractor (with condenser). The condenser and heating mantle were then activated and extraction carried on for
$4 \mathrm{~h}$. At the end of extraction, the solvent was evaporated and the flask dried in the oven (at $60{ }^{\circ} \mathrm{C}$ ). The flask was then cooled and reweighed. The percentage crude fat (CF) was calculated using the formula:

$$
C F(\%)=\frac{M e x}{M s} \times 100
$$

where $M e x=$ mass of extract $(\mathrm{g})$ and $M s=$ mass of sample used (g).

Crude proteins and total sugars were determined respectively with the Kjeldahl technique (Jung et al., 2003) and a procedure reported by Ahmmed et al. (2015). Crude fibres contents were determined according to AOAC (2000).

Concerning crude proteins determination, the macro-Kjeldahl procedure used was the Corn Refiners Association method A-18. Samples of $1 \mathrm{~g}$ were weighed and then digested with $17 \mathrm{ml}$ of concentrated sulfuric acid plus one catalyst tablet containing $5.57 \mathrm{~g}$ of $\mathrm{K}_{2} \mathrm{SO}_{4}, 0.033 \mathrm{~g}$ of $\mathrm{CuSO}_{4}$, and $0.2 \mathrm{~g} \mathrm{TiO}_{2}$. The alkaline distillation environment was produced by $40 \% \mathrm{NaOH}$ to produce an alkaline distillation environment and $4 \%$ boric acid solution to collect the distilled ammonia. The titrations were performed with standardized $0.1 \mathrm{~N}$ hydrochloric acid. Tashiro's indicator was used to identify the end point of the titration $(0.375 \mathrm{~g}$ of methyl red and $0.250 \mathrm{~g}$ of methylene blue in $300 \mathrm{ml}$ of $95 \%$ ethanol).

As for total sugar determination, $5 \mathrm{~g}$ of spice sample were taken in a $500 \mathrm{ml}$ beaker. One hundred milliliters of warm water were added and neutralized with $10 \%$ $\mathrm{NaOH}$. Two milliliters of lead acetate solution were added and kept during $10 \mathrm{~min}$. The necessary amount of sodium oxalate solution was added to remove the excess lead. The volume was made up to $250 \mathrm{ml}$ with distilled water and filtered. Fifty milliliters of the clarified and deleaded solution were transferred to a $250 \mathrm{ml}$ flask and then $10 \mathrm{ml}$ of $1 \mathrm{~N} \mathrm{HCl}$ were added. This solution was boiled for $2 \mathrm{~min}$. After cooling, 2-3 drops of phenolphthalein were added and the contents were neutralized with $\mathrm{NaOH}$. The solution was filtered and the volume was made $250 \mathrm{ml}$. Thus the sample solution was prepared. Ten milliliters of a mixed Fehling's solution ( $5 \mathrm{ml}$ Fehling's solution- 1 and $5 \mathrm{ml}$ Fehling's solution-2) were pipetted into a conical flask. A burette was filled with the clarified sample solution and running the whole volume required to reduce the Fehling's solutions so that $0.5-1 \mathrm{ml}$ was still required to complete the titration. The content of the flask was mixed and then heated to boiling for $2 \mathrm{~min}$. Three drops of methylene blue indicator were added. Then the titration continued till color completely disappeared. The percentage of total sugar was calculated by the following formula: 


$$
\begin{gathered}
m \text { g reducing sugars per } 100 \mathrm{ml}=\frac{\text { Factor } \times 100}{\text { Titre }} \\
\% \text { of reducing sugar }=\frac{m g \cdot 100 \mathrm{ml}^{-1} \times \text { dilution } \times 100}{\text { weight of the samples } \times 1,000}
\end{gathered}
$$

The factor is obtained from the invert sugar table by Pearson.

Determination of energy values of spice samples. The energy value of the samples was determined by multiplying the protein content by four, the carbohydrate content by four and the fat content by nine (AOAC, 1990):

Energy Value $=($ Crude protein $\times 4)+($ Total carbohydrate $\times 4)+($ Crude fat $\times 9)$ AOAC

Water activity $\left(a_{w}\right)$ and $\mathbf{p H}$ determination. The water activity of spices was determined from the fruit paste using an electronic hygrometer $\left(\mathrm{a}_{\mathrm{w}}-\right.$ Win, Rotronic, Huntington, NY, USA) equipped with a calibrated probe of $0.1-0.95$ with a solution of $\mathrm{LiCl}$ of known activity. The $\mathrm{pH}$ was determined by a digital $\mathrm{pH}$ meter according to Hildebrant (2016).

\subsection{Total polyphenols and total flavonoids analysis}

Total polyphenols content (TPP) was assessed using the Folin-Ciocalteau colorimetric method (Moukette et al., 2015) with few modifications, calculated from the Gallic Acid standard curve $(0-1,000 \mu \mathrm{g}$. $\mathrm{ml}^{-1}$ ) and expressed as mg GAE.g ${ }^{-1} \mathrm{dw}$ (mg Gallic Acid Equivalent. ${ }^{-1}$ dry weight). The total flavonoids content (TFL) was also quantified (Alara et al., 2017) from a Catechin standard curve $\left(0-1,000 \mu \mathrm{g} \cdot \mathrm{ml}^{-1}\right)$ and expressed as $\mathrm{mg} \mathrm{CE} \cdot \mathrm{g}^{-1} \mathrm{dw}$ (mg Catechin Equivalent. $\mathrm{g}^{-1}$ dry weight).

\subsection{In vitro antioxidant activities of aqueous plant extracts}

Total antioxidant activity (TAC). Two reducing power activities were used. Total antioxidant activity (TAC) was determined by the phosphomolybdenum method (Prieto et al., 1999). This technique is based on the reduction of molybdenum Mo (VI) to molybdenum Mo (V) in the presence of the extract $\left(5 \mathrm{mg} \cdot \mathrm{ml}^{-1}\right)$ to form a green phosphate/Mo (V) complex with an acidic $\mathrm{pH}$, the color intensity of which is measured at $695 \mathrm{~nm}$ against white. Trolox was used as a positive control and the reducing activity was expressed as $\mathrm{mg} \mathrm{TE} \cdot \mathrm{g}^{-1}$ $\mathrm{dw}$ (mg Trolox Equivalent. $\mathrm{g}^{-1}$ dry weight) based on the Trolox calibration curve.
Ferric Reducing Antioxidant Power (FRAP). The reducing power of the extract $\left(5 \mathrm{mg} \cdot \mathrm{ml}^{-1}\right)$ is also measured by the Ferric Reducing Antioxidant Power (FRAP), according to Kim (2012). This test estimates the potential of spice antioxidants $\left(5 \mathrm{mg} \cdot \mathrm{ml}^{-1}\right)$ to reduce ferric iron to ferrous iron. In the presence of spice antioxidants, potassium ferrocyanide, trichloroacetic acid and iron chloride form an absorbing complex at $700 \mathrm{~nm}$. Ascorbic Acid (AA) was used as a reference and the results were expressed as mg AAE. $\mathrm{g}^{-1} \mathrm{dw}$ based on the AA calibration curve.

Lipid Peroxidation (LP) inhibition assay. An adapted Thiobarbituric Acid Reactive Species (TBARS) assay was used to quantify the lipid peroxide formed using egg yolk homogenates as lipid-rich media according to Nguyen et al. (2017). One milliliter of each concentration $\left(0,1,2,3,4\right.$ and $\left.5 \mathrm{mg} \cdot \mathrm{ml}^{-1}\right)$ was tested and the inhibition was measured at $532 \mathrm{~nm}$. Butylhydroxytoluene (BHT) prepared at different concentrations was used as a reference and the results were expressed as the sample concentration providing $50 \%$ inhibition $\left(\mathrm{IC}_{50}: \mathrm{mg} \cdot \mathrm{ml}^{-1}\right)$ values.

1,1-diphenyl-2-picrylhydrazyl (DPPH) scavenging activity. The method is based on the reducing of absorbance at $517 \mathrm{~nm}$, resulting from the initial color change as the radical is trapped by the antioxidants contained in the samples $\left(0,1,2,3,4\right.$ and $\left.5 \mathrm{mg} \cdot \mathrm{ml}^{-1}\right)$ to be analyzed through the transfer of a hydrogen atom to form a stable DPPH-H according to Nguyen et al. (2017), with slight modifications. Inhibition was read at $517 \mathrm{~nm}$ against a DPPH control. The results were expressed as $\mathrm{IC}_{50}\left(\mathrm{mg} \cdot \mathrm{ml}^{-1}\right)$ values and AA was used as a reference.

\subsection{Statistical analysis}

MINITAB 18.0 (Pennsylvania, PA, USA) (13.0) was used for statistical analysis. All tests were repeated three times and the results are presented as the mean \pm standard deviation. The analysis of variance was performed using raw data and differences between the means were analyzed using the Tukey's multiple range tests with significance defined at the $p<0.05$ level.

\section{RESULTS}

\subsection{Preliminary studies}

Preliminary tests were achieved in order to identify the roasting parameters (temperature and time) where the recovery of total polyphenols (TPP) is the highest. Following the single factor multiple levels approach, the results obtained are presented on figure 2 . 
The results show that TPP content significantly $(p<0.05)$ increases as temperature rises to $140{ }^{\circ} \mathrm{C}$, and then significantly decreases at around $160{ }^{\circ} \mathrm{C}$, with constant roasting time (15 $\mathrm{min}$ ) for T. tetraptera fruits. Indeed, the highest TPP content (32.94 mg GAE. $\mathrm{g}^{-1}$ dw) was obtained at a roasting temperature of $140{ }^{\circ} \mathrm{C}$. With regard to $A$. citratum fruits, the increase in TPP is seen up to $180{ }^{\circ} \mathrm{C}$ and at that temperature, TPP content is $6.71 \mathrm{mg} \mathrm{GAE} \cdot \mathrm{g}^{-1} \mathrm{dw}$. A significant decrease on TPP content is noticed after this temperature. The TPP content of both spices was also influenced significantly by the roasting time. Definitely, TPP content rises with the roasting time up to $10 \mathrm{~min}$ for T.tetraptera fruits and up to $20 \mathrm{~min}$ for $A$. citratum fruits at a fixed roasting temperature of $140{ }^{\circ} \mathrm{C}$ (Figure 2).

The formulation 95/5 (T.tetrapteralA. citratum) possesses the highest phenolic compounds content and was kept for the further analysis. The final roasting parameters retained for the further investigations were $140{ }^{\circ} \mathrm{C}$ during $10 \mathrm{~min}$ for $T$. tetraptera fruits, $180{ }^{\circ} \mathrm{C}$ during $20 \mathrm{~min}$ for $\mathrm{A}$. citratum fruits and $150{ }^{\circ} \mathrm{C}$ during $12 \mathrm{~min}$ for the formulation.

\subsection{Effect of roasting on the physicochemical characteristics of spices}

The heat treatment applied on the spices has significantly influenced most of the characteristics studied except: $\mathrm{pH}, a_{w}$, ash and crude protein contents. The results are presented on tables $\mathbf{1}$ and $\mathbf{2}$ below.

The dry matter is reducing after roasting compared to before in both plant species and in the formulation. Indeed, there was a reduction in dry matter content of almost $2.81 \%, 2.61 \%$, and $1.71 \%$, (respectively, for T.tetraptera, A.citratum and the formulation) compared to the unheated spices. The decrease in dry
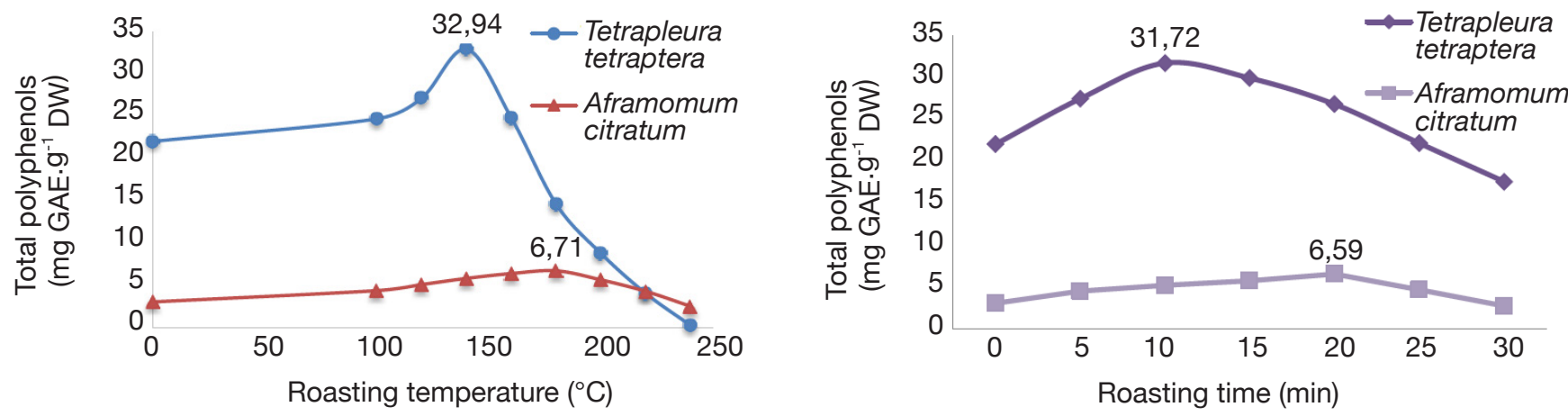

Figure 2. Total polyphenols contents of spices using different roasting temperatures (roasting time: 15 min) and different roasting times (roasting temperature: $140^{\circ} \mathrm{C}$ ), respectively - Teneurs en polyphénols totaux des épices respectivement à différentes températures de torréfaction (temps de torréfaction : $15 \mathrm{~min}$ ) et à différents temps de torréfaction (température de torréfaction : $140{ }^{\circ} \mathrm{C}$ ).

Table 1. Proximate composition (on dry weight basis) of raw and roasted fruits of Tetrapleura tetraptera, Aframomum citratum and the formulation - Quelques caractéristiques chimiques (sur poids sec) des fruits de Tetrapleura tetraptera, Aframomum citratum et d'une formulation des deux épices avant et après le traitement thermique.

\begin{tabular}{|c|c|c|c|c|c|c|}
\hline \multirow[b]{2}{*}{ Types of spices } & \multicolumn{2}{|c|}{ Dry matter (\%) } & \multicolumn{2}{|l|}{ Ash (\% DW) } & \multicolumn{2}{|c|}{ Crude proteins (\% DW) } \\
\hline & Non-roasted & Roasted & Non-roasted & Roasted & Non-roasted & Roasted \\
\hline T.tetraptera & $77.12 \pm 0.05^{\mathrm{a}}$ & $75.01 \pm 0.13^{b}$ & $2.69 \pm 0.10$ & $2.75 \pm 0.14$ & $3.25 \pm 0.17$ & $3.17 \pm 0.02$ \\
\hline A. citratum & $86.97 \pm 0.02^{\mathrm{a}}$ & $84.76 \pm 0.01^{\mathrm{b}}$ & $4.14 \pm 0.02$ & $4.38 \pm 0.05$ & $5.44 \pm 0.03$ & $5.02 \pm 0.13$ \\
\hline \multirow[t]{2}{*}{ Formulation $(95 / 5)$} & $78.27 \pm 0.02^{\mathrm{a}}$ & $76.95 \pm 0.06^{\mathrm{b}}$ & $2.75 \pm 0.05$ & $3.09 \pm 0.04$ & $4.01 \pm 0.06$ & $3.84 \pm 0.12$ \\
\hline & \multicolumn{2}{|c|}{ Crude fats (\% DW) } & \multicolumn{2}{|c|}{ Total sugars (\% DW) } & \multicolumn{2}{|c|}{ Crude fibers (\% DW) } \\
\hline Types of spices & Non-roasted & Roasted & Non-roasted & Roasted & Non-roasted & Roasted \\
\hline T.tetraptera & $9.06 \pm 0.05^{\mathrm{a}}$ & $8.36 \pm 0.11^{b}$ & $55.06 \pm 0.03^{\mathrm{a}}$ & $53.91 \pm 0.08^{b}$ & $4.25 \pm 0.06^{\mathrm{b}}$ & $5.85 \pm 0.03^{\mathrm{a}}$ \\
\hline A. citratum & $13.22 \pm 0.07^{\mathrm{a}}$ & $12.89 \pm 0.27^{b}$ & $30.45 \pm 0.08^{\mathrm{a}}$ & $28.15 \pm 0.10^{\mathrm{b}}$ & $31.04 \pm 0.07^{\mathrm{b}}$ & $33.94 \pm 0.11^{\mathrm{a}}$ \\
\hline Formulation $(95 / 5)$ & $9.41 \pm 0.12^{\mathrm{a}}$ & $8.87 \pm 0.21^{\mathrm{b}}$ & $55.76 \pm 0.13^{\mathrm{a}}$ & $54.47 \pm 0.03^{\mathrm{b}}$ & $4.65 \pm 0.05^{\mathrm{b}}$ & $6.82 \pm 0.07^{\mathrm{a}}$ \\
\hline
\end{tabular}

Means with different subscripts $(\mathrm{a}, \mathrm{b})$ on the same line are significantly different $(p<0.05)$ - les moyennes suivies de lettres différentes $(a, b)$ sont significativement différentes ( $\mathrm{p}<0,05)$; DW: Dry Weight - poids sec. 
Table 2. Some of the physical characteristics of raw and roasted fruits of Tetrapleura tetraptera and Aframomum citratum Quelques caractéristiques physiques des fruits de Tetrapleura tetraptera, Aframomum citratum et d'une formulation des deux épices avant et après le traitement thermique.

\begin{tabular}{|c|c|c|c|c|c|c|}
\hline \multirow[b]{2}{*}{ Types of spices } & \multicolumn{2}{|c|}{ Total energy $\left(\mathrm{Kcal} \cdot 100 \mathrm{~g}^{-1} \mathrm{DW}\right)$} & \multicolumn{2}{|l|}{ pH } & \multicolumn{2}{|l|}{$\mathbf{a}_{w}$} \\
\hline & Non-roasted & Roasted & Non-roasted & Roasted & Non-roasted & Roasted \\
\hline T. tetraptera & $314.78 \pm 0.21$ & $305.56 \pm 0.12$ & $4.61 \pm 0.04$ & $5.01 \pm 0.02$ & $0.44 \pm 0.02$ & $0.39 \pm 0.00$ \\
\hline A. citratum & $262.54 \pm 0.11^{\mathrm{a}}$ & $248.69 \pm 0.30^{\mathrm{b}}$ & $5.83 \pm 0.05$ & $6.12 \pm 0.05$ & $0.27 \pm 0.04$ & $0.24 \pm 0.01$ \\
\hline Formulation $(95 / 5)$ & $323.77 \pm 0.11^{\mathrm{a}}$ & $313.07 \pm 0.14^{\mathrm{b}}$ & $4.68 \pm 0.10$ & $5.07 \pm 0.07$ & $0.42 \pm 0.03$ & $0.38 \pm 0.02$ \\
\hline
\end{tabular}

Means with different subscripts $(\mathrm{a}, \mathrm{b})$ on the same line are significantly different $(p<0.05)$ - les moyennes suivies de lettres différentes $(a, b)$ sont significativement différentes ( $\mathrm{p}<0,05)$; DW: Dry Weight - poids sec.

matter after heat treatment was accompanied by a nonsignificant drop in $a_{w}(11.36 \%, 11.11 \%, 9.52 \%)$ and a non-significant increase in $\mathrm{pH}(10.85 \%, 5 \%, 8.33 \%)$ for $T$. tetraptera, A. citratum and the mix, respectively. It was also noted that roasting did not significantly affect the ash content but it has significantly increased the amount of raw fibers for $37.64,9.34$ and $46.66 \%$ respectively for $T$. tetraptera, $A$. citratum and the mix.

On the other hand, crude fat contents in the spices were significantly $(p<0.05)$ reduced by about $7.72 \%$, $2.5 \%$ and $5.74 \%$ (for T.tetraptera, A. citratum and the formulation, respectively) after heat treatment. Crude protein and total sugars contents also showed a significant decrease of about $12.92 \%, 7.72 \%$ and $4.23 \%$; and $2.09 \%, 7.55 \%$ and $2.31 \%$ (for T. tetraptera, A. citratum and the formulation respectively).

\subsection{Effects of heat treatment on total phenolic and total flavonoids contents}

Total polyphenols and flavonoids contents of the different spices aqueous extracts before and after the heat treatment are recorded in table 3 . According to table 3, the two spices and the formulation contain significant amounts of polyphenols and flavonoids before and after heat treatment. The amounts of total polyphenols increased after the treatment as following: 26.92-29.51, 3.94-5.13 and 26.11-32.26 mg EAG.g ${ }^{-1}$ $\mathrm{dw}$ respectively for $T$. tetraptera, A. citratum and the formulation. The changes on the flavonoids contents of both spices are similar with the modifications registered while testing the polyphenol contents. We can also notice that the amounts of phenolic compounds registered in the formulation are greater than those recorded in the individual spices. For both spices, before and after heat treatment, there was a significant $(p<0.05)$ positive correlation between TPP and TFL of extracts, as shown in table 4.

\subsection{Effects of heat treatment on spices antioxidant activities}

The results related to the study of the in vitro antioxidant activities of spices before and after roasting are shown in table 5. Tetrapleura tetraptera and the mix extracts possess the smallest $\mathrm{IC}_{50}\left(\mathrm{mg} \cdot \mathrm{ml}^{-1}\right)$ for DPPH and LP assays and the highest reductive activities for FRAP and TAC assays. However, the extracts activities are less than the reference's (BHT, Ascorbic acid) antioxidant activities.

Table 3. Total polyphenols and total flavonoids content of raw and roasted fruits of Tetrapleura tetraptera, Aframomum citratum and the formulation - Teneurs en polyphénols et flavonö̈des totaux des fruits de Tetrapleura tetraptera, Aframomum citratum et d'une formulation des deux épices avant et après le traitement thermique.

\begin{tabular}{|c|c|c|c|c|}
\hline & Type of spices & T. tetraptera & A. citratum & Formulation $(95 / 5)$ \\
\hline \multirow[t]{2}{*}{ Total polyphenols (mg EAG.g ${ }^{-1} \mathrm{DW}$ ) } & Non roasted & $26.92 \pm 0.05^{b}$ & $3.94 \pm 0.10^{\mathrm{b}}$ & $29.11 \pm 0.03^{\mathrm{a}}$ \\
\hline & Roasted & $29.51 \pm 0.05^{\mathrm{a}}$ & $5.13 \pm 0.04^{\mathrm{a}}$ & $32.26 \pm 0.10^{\mathrm{a}}$ \\
\hline \multicolumn{2}{|c|}{ Percentage difference } & $8.78 \%$ & $23.20 \%$ & $9.76 \%$ \\
\hline \multirow[t]{2}{*}{ Total flavonoids (mg EC $\left.\cdot \mathrm{g}^{-1} \mathrm{DW}\right)$} & Non roasted & $0.63 \pm 0.03^{b}$ & $0.28 \pm 0.02$ & $0.65 \pm 0.01^{\mathrm{b}}$ \\
\hline & Roasted & $0.71 \pm 0.03^{\mathrm{a}}$ & $0.33 \pm 0.01$ & $0.72 \pm 0.01^{\mathrm{b}}$ \\
\hline \multicolumn{2}{|c|}{ Percentage difference } & $11.27 \%$ & $15.15 \%$ & $9.72 \%$ \\
\hline
\end{tabular}

Means with different superscripts $(\mathrm{a}, \mathrm{b})$ on the same line are significantly $(p<0.05)$ different - les moyennes suivies de lettres différentes ( $a, b)$ sont significativement différentes ( $\mathrm{p}<0,05$ ); GAE: Gallic Acid Equivalent - Équivalent Acide Gallique; CE: Catechin Equivalent - Équivalent Catéchine; DW: Dry Weight - poids sec. 
Table 4. Mean correlations between total polyphenols and total flavonoids of raw and roasted fruits of Tetrapleura tetraptera, Aframomum citratum and the formulation - Corrélations entre les teneurs en polyphénols totaux et flavonö̈des totaux des fruits de Tetrapleura tetraptera, Aframomum citratum et d'une formulation des deux épices avant et après le traitement thermique.

\begin{tabular}{llll}
\hline Spices & Type of spices & Equation & Coefficient of determination \\
\hline T. tetraptera & Non-roasted & $\mathrm{y}=0.087 \mathrm{x}-1.70$ & 0.95 \\
& Roasted & $\mathrm{y}=0.090 \mathrm{x}-1.96$ & 0.97 \\
\hline A. citratum & Non-roasted & $\mathrm{y}=0.06 \mathrm{x}+0.15$ & 0.99 \\
& Roasted & $\mathrm{y}=0.076 \mathrm{x}-0.07$ & 0.97 \\
\hline Formulation (95/5) & Non-roasted & $\mathrm{y}=0.052 \mathrm{x}-0.83$ & 0.91 \\
& Roasted & $\mathrm{y}=0.037 \mathrm{x}-0.46$ & 0.97 \\
\hline
\end{tabular}

Table 5. Some of the in vitro antioxidant activities of aqueous extracts of raw and roasted fruits of Tetrapleura tetraptera, Aframomum citratum and the formulation - Quelques activités antioxydantes in vitro des extraits aqueux des fruits de Tetrapleura tetraptera, Aframomum citratum et d'une formulation des deux épices avant et après le traitement thermique suivant trois modes d'extraction.

\begin{tabular}{llccc}
\hline & Type of spices & T. tetraptera & A. citratum & Formulation (95/5) \\
\hline TAC $\left(\mathrm{mg} \mathrm{TE} \cdot \mathrm{g}^{-1} \mathrm{DW}\right)$ & Non-roasted & $36.28 \pm 0.10^{\mathrm{b}}$ & $8.94 \pm 0.10^{\mathrm{b}}$ & $37.04 \pm 0.17^{\mathrm{b}}$ \\
& Roasted & $39.01 \pm 0.16^{\mathrm{a}}$ & $11.02 \pm 0.33^{\mathrm{a}}$ & $39.98 \pm 0.12^{\mathrm{a}}$ \\
\hline FRAP $\left(\mathrm{mg} \mathrm{AAE} \cdot \mathrm{g}^{-1} \mathrm{DW}\right)$ & Non-roasted & $8.91 \pm 0.13^{\mathrm{b}}$ & $4.11 \pm 0.16^{\mathrm{b}}$ & $10.09 \pm 0.11^{\mathrm{b}}$ \\
& Roasted & $10.39 \pm 0.07^{\mathrm{a}}$ & $5.86 \pm 0.13^{\mathrm{a}}$ & $12.30 \pm 0.13^{\mathrm{a}}$ \\
\hline Lipid peroxidation inhibition $_{\left(\mathrm{IC}_{50}: \mathrm{mg} \cdot \mathrm{ml}^{-1}\right)}$ & Non-roasted & $2.98 \pm 0.02^{\mathrm{c}}$ & $8.28 \pm 0.12^{\mathrm{c}}$ & $2.37 \pm 0.04^{\mathrm{b}}$ \\
& Roasted & $1.71 \pm 0.04^{\mathrm{b}}$ & $6.81 \pm 0.12^{\mathrm{b}}$ & $1.44 \pm 0.06^{\mathrm{b}}$ \\
& Reference (BHT) & $0.41 \pm 0.01^{\mathrm{a}}$ & $0.41 \pm 0.01^{\mathrm{a}}$ & $0.41 \pm 0.01$ \\
\hline DPPH inhibition $\left(\mathrm{IC}_{50}: \mathrm{mg} \cdot \mathrm{ml}^{-1}\right)$ & Non-roasted & $3.85 \pm 0.05^{\mathrm{b}}$ & $11.42 \pm 0.07^{\mathrm{c}}$ & $3.46 \pm 0.05^{\mathrm{c}}$ \\
& Roasted & $3.02 \pm 0.02^{\mathrm{b}}$ & $9.92 \pm 0.08^{\mathrm{b}}$ & $2.72 \pm 0.02^{\mathrm{b}}$ \\
& Reference (ascorbic acid) & $0.15 \pm 0.01^{\mathrm{a}}$ & $0.15 \pm 0.01^{\mathrm{a}}$ & $0.15 \pm 0.01^{\mathrm{a}}$ \\
\hline
\end{tabular}

Means with different superscripts $(\mathrm{a}, \mathrm{b}, \mathrm{c})$ on the same line are significantly $(p<0.05)$ different - les moyennes suivies de lettres différentes $(a, b, c)$ sont significativement différentes ( $\mathrm{p}<0,05)$; GAE: Gallic Acid Equivalent - Équivalent Acide Gallique; CE: Catechin Equivalent - Équivalent Catéchine; DW: Dry Weight - poids sec; BHT: Butylhydroxytoluene - Butyl hydroxytoluène; TAC: Total Antioxidant activity - Capacité antioxydante totale: FRAP: Ferric Reductive Antioxidant Power - Pouvoir antioxydant réducteur du fer; DPPH: 1,1-Diphenyl-2-picrylhydrazyl - 1,1-Diphenyl-2-picrylhydrazyl; TE: Trolox Equivalent - Équivalent Trolox.

It can also be noticed that the roasted extracts for both spices had the highest percentage of radical entrapment and the highest reductive power compared to the raw extracts. It is clear that the higher the concentrations, the greater the antioxidant activities for DPPH and LP assays. However, it was found that no lipid peroxidation inhibition was observed at concentrations below $1 \mathrm{mg}$. $\mathrm{ml}^{-1}$; also, putting those spices together at the same concentration (95/5: T. tetraptera/A. citratum) caused an improvement in the studied biological activities.

The study of correlations between TPP, TFL and antioxidant activities was performed and the results are presented in figure 3 . Strong positive significant $(p<0.05)$ correlations were found between phenolic compounds and TAC, FRAPP assays while strong negative significant correlations were established between the phenolic compounds and DPPH and lipid peroxidation inhibition assays as they are expressed as $\mathrm{IC}_{50}\left(\mathrm{mg} \cdot \mathrm{ml}^{-1}\right)$. Negative correlations imply that a higher phenolic or flavonoid content leads to lower $\mathrm{IC}_{50}$ values and higher antioxidant potential. The same observations were made with the DPPH and LP inhibition assays and the TAC and FRAP assays.

\section{DISCUSSION}

Heat treatment is one of the most foods processing actions used during food transformation. The target thermal effects (microbial forms destruction, enzyme inactivation, poison degradation, sensory changes, and nutritional improvement) can be followed by collateral thermal effects (useful microflora and enzyme destruction, harmful substances neoformation, 


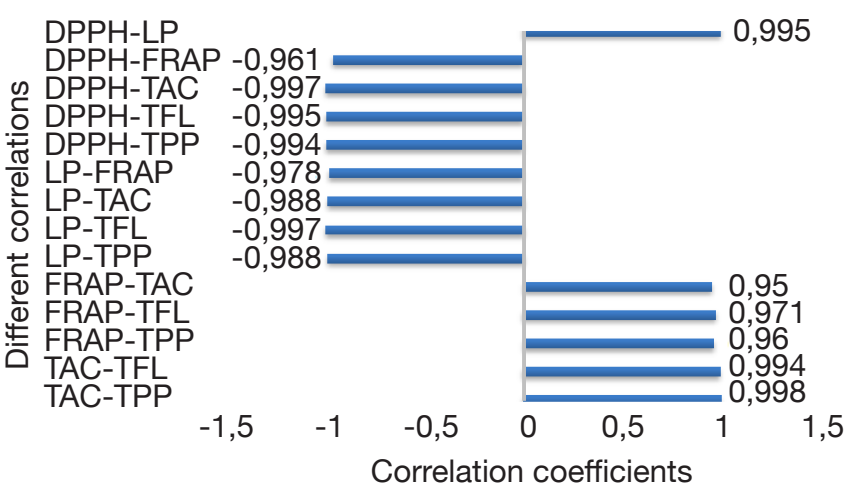

Figure 3. Mean correlation coefficients between FRAP, DPPH, LP and TAC assays and total polyphenols and total flavonoids contents of the various spices - Coefficients de corrélation moyens entre les activités antioxydantes (FRAP, $D P P H, L P, T A C)$ des extraits d'épices et les contenus en polyphénols et flavonoïdes totaux.

FRAP: Ferric Reductive Antioxidant Power - pouvoir antioxydant réducteur du fer; DPPH: 1,1-Diphenyl-2picrylhydrazyl - 1,1-Diphenyl-2-picrylhydrazyl; LP: Lipid Peroxidation inhibition - inhibition de la peroxidation lipidique; TAC: Total Antioxidant activity - capacité antioxydante totale; TPP: Total Polyphenols - teneur en polyphénols totaux; TFL: Total Flavonoids - teneur en flavonoïdes totaux; *: $p<0.05-$ $\mathrm{p}<0,05$.

nutritional and healthiness loss). Spices generally used for flavoring dishes are an excellent source of bioactive compounds with good antioxidant activities. Roasting the spices as a heat treatment for culinary purposes is commonly used by women among other to improve the release of various aromas and to facilitate the crushing. The objective of this study was to find out how high temperatures can affect the chemical composition (among this the phenolic compounds and the physicochemical composition) and the antioxidant activities of two spices, T. tetraptera and A. citratum extracts mostly used together and roasted for culinary and therapeutic purposes. Unfortunately, the scarcity of data on the physicochemical, phytochemical changes and the biological activities modifications of these spices extracts after heat treatment was a limit for a valuable comparison.

\subsection{Preliminary tests}

After heat treatment, it has been demonstrated that modifications occur on the chemical composition of the spices. During the preliminary tests, increasing roasting temperature and roasting time significantly increased the polyphenols contents of both spices up to a certain level (optimal zone). The reverse effect was observed by increasing the two factors after that critical level. The observed effects are common to the results obtained when food is submitted to prolonged heat treatments. For example, Khatun et al. (2006) ${ }^{1}$ cited by Nikousaleh \& Prakash (2016) reported an increase in total phenolic compounds on heated $S$. aromaticum seeds (roasted on medium flame for 5 min with continuous stirring in a thick bottom pan). Few years earlier, Xu et al. $(2008)^{2}$ cited by Lemos et al. (2012) reported that the thermal treatment applied to foods of plant origin by heating or roasting causes evaporation of intracellular water, triggering chemical reactions that can change the lignocellulosic structure and promotes protein denaturation, which might result in a greater availability of plant phenolic compounds. Indeed, heat treatment and/or enzyme digestion can break the non-covalent and covalent associations of polyphenols with food macromolecule. However, roasting both spices at temperatures of more than $140{ }^{\circ} \mathrm{C}$ (T.tetraptera and the formulation) and $180{ }^{\circ} \mathrm{C}$ (A. citratum fruits) using roasting time higher than $10 \mathrm{~min}$ (T.tetraptera and the formulation) and 20 min (A.citratum fruits) was detrimental to the phenolic contents. The observed differences are due to the physicochemical structure and composition of both spices. Indeed, the seed coat of A. citratum fruits seems to be physically and visually more resistant to heat than T.tetraptera fruits coat. After the critical zone, the drop on phenolic compounds is probably due to high roasting temperatures and long exposure to high temperatures. Similar results were obtained by Neelam et al. (2018) while roasting cowpea cultivars in hot air oven at $160{ }^{\circ} \mathrm{C}$ for $45 \mathrm{~min}$.

\subsection{Physicochemical changes}

According to Tumuluru (2016), torrefaction is defined as slowly heating the biomass in an inert atmosphere to a maximum temperature of $300{ }^{\circ} \mathrm{C}$ which will result in a solid uniform product with lower moisture and higher energy content when compared to raw biomass. Various biomass reactions occur during torrefaction (devolatilization and carbonization of hemicellulose, depolymerization and devolatilization/softening of lignin, and depolymerization and devolatilization of cellulose). These reactions result in changes (in biomass moisture, chemical composition, energy content) and therefore increase/decrease the extractability of certain constituents. However, it should be reported that the final effect of a thermal process on food depends on parameters like food matrices, the physicochemical

\footnotetext{
${ }^{1}$ Khatun M. et al., 2006. Effect of thermal treatment on radicalscavenging activity of some spices. Food Sci. Technol. Res., 12(3), 178-185, doi.org/10.3136/fstr.12.178

${ }^{2} \mathrm{Xu}$ et al., 2008. Phénoliques totaux, acides phénoliques, isoflavones et propriétés antioxydantes du soja jaune et noir affectés par le traitement thermique. J.Agric. Food Chem., 56, 7165-7175.
} 
nature of the food, the types of heat treatments (boiling, steaming, roasting, frying, etc.).

Submitting the various spices to the previously defined roasting parameters has modified their physicochemical parameters. The decrease in dry matter for both spices after heat treatment can be explained by the unconditional loss of moisture by evaporation during the treatment and by the reduction in fat, total sugar and protein contents noticed on both heated spices (Tumuluru, 2016). Tetrapleura tetraptera and A.citratum fruits as spices contain volatile and thermolabile compounds. The volatile content of T.tetraptera fruits and leaves is composed of high percentage of lower acids and esters, limonene, linalool, 1,8-cineole, phytol, $\alpha$-pinene (Ngassoum et al., 2001; Abaoba et al., 2009) while A.citratum fruits possess high percentages of sesquiterpene, monoterpene hydrocarbons and geraniol according to Meffo et al. (2019). Uyoh et al. (2013) reported also the presence of vitamins A $\left(2.64-4.72 \mu \mathrm{g} \cdot \mathrm{g}^{-1}\right), \mathrm{E}(2.42-$ $3.74 \%)$ and $\mathrm{C}\left(0.79-1.25 \mathrm{mg} \cdot 100 \mathrm{~g}^{-1}\right)$ in T.tetraptera fruits. During heat treatment, these compounds can be destroyed or volatilized and then give an explanation on the drop of dry matter during the process. Polovka \& Suhaj (2010) in a review of the effect of heat treatment on culinary herbs and spices composition reported that the decrease in the content of some taste and aromainfluencing components (safrole, pipperine, capsaicine or curcumine) occurs from drying, microwave processing, boiling or pressure cooking, beginning at a temperature of $70{ }^{\circ} \mathrm{C}$. Vega-Galvez et al. (2009) $)^{3}$ cited by Polovka \& Suhaj (2010) have also revealed the decrease of vitamin $\mathrm{C}$ content in red pepper under convective drying at $50-95{ }^{\circ} \mathrm{C}$.

The observed loss of moisture on both heated spices would also explain the decrease in $a_{w}$ for the different spices. It is reported that high temperatures generally contribute to the reduction of the moisture content which will reduce the water activity and inhibit several chemical reactions and biological activities which can reduce the quality of food (Djikeng et al., 2018). The increase in $\mathrm{pH}$ observed after heat treatment can be due to the loss of organic acids which caused the decrease in acid content, and hence increased the $\mathrm{pH}$ value of the spices as it has been reported on heated mengkudu (Morinda citrifolia L.) extracts by Igual et al., $2010^{4}$ cited by Maskat \& Tan (2011).

A significant reduction in fat content after heat treatment on both spices was also registered. The results obtained are similar to Domiszewski et al. (2011) findings that investigate on the effects of different

\footnotetext{
${ }^{3}$ Vega-Gálvez A. et al., 2009. Effect of air-drying temperature on physico-chemical properties, antioxidant capacity, colour and total phenolic content of red pepper (Capsicum annuum, L. var. Hungarian). Food Chem., 117(4), 647-653, https://doi. org/10.1016/j.foodchem.2009.04.066
}

heat treatments (boiling, microwave cooking, frying) on lipid quality of catfish (Pangasus hypophthalmus). According to their report, the decrease on the total fat content during heat treatment has been caused by the loss of lipid volatiles following the spread of fat in the matrix. In another report on the effect of different cooking methods on nutritional composition of salmon (Salmo salar L.) and chilean jack mackerel (Trachurus murphyi Nichols) fillets, Bastías et al. (2017) stated that this reduction in fat content can be a consequence of higher fat oxidation with higher temperatures and higher heat exposure times.

It is reported that one of the most predominant reactions that occurs during the heat treatment of food matrices containing proteins is the Maillard reaction, the consequences of which may be detrimental/ beneficial for the nutritional value. The outcome of these reactions is related to temperature, time of exposure to heat treatments, and the physicochemical composition of food (Tumuluru, 2016). The decrease in protein content after heat treatment, although not significant, can then be explained by Maillard reaction. In fact, at prolonged temperatures, there will be reactions leading to the reduction of the nutritional value of proteins by decreasing their bioavailability, by denaturation and by the formation of undesirable compounds (Bastías et al., 2017).

Thermal degradation of sugars, which may occur by two different major reaction pathways (the Maillard reaction and caramelisation) can explain the drop in total sugars content noted after the process, according to Woo et al. (2015). This generally occurs when simple sugars are heated at high temperatures. Consequently, the reduction in total sugar, fat and protein contents has significantly $(p<0.05)$ affected the total energy of A. citratum and the mixed spices.

At the opposite, an increase on total fiber content was noticed after heat treatment. Devinder et al. (2012) reported that simple processes such as soaking and cooking tend to modify the composition and availability of fiber content by modifying the plant cell wall material. Other methods are used for thermal modification (sterilization, sun drying, steam processing, boiling, frying - mainly deep fat frying - , microwave drying, vacuum-belt drying, roasting and pressure cooking) and the modifications occur on the soluble and insoluble fibers ratio and physicochemical properties of dietary fiber (Ain et al., 2019). The amount of soluble dietary fiber produced is highly dependent on the temperature, high temperature breaking the

\footnotetext{
${ }^{4}$ Igual M., Garcia-Martinez E., Camacho M.M. \& MartinezNavarrete N., 2010. Effect of thermal treatment and storage on the stability of organic acids and the functional value of grapefruit juice. Food Chem., 118, 291-299, https://doi.org/10.1016/j. foodchem.2009.04.118
} 
glycosidic bonds in polysaccharide, which can lead to the release of oligosaccharides and thus increase the quantity of soluble dietary fiber. The increase in raw fibers can be also explained by the hydrolysis of polymers stored in food matrices during heat treatment (Mullin \& Smith, 1991). Indeed, in all the cooking treatments of potatoes (boiled, microwaved, baked) the apparent total dietary fiber (insoluble and soluble fiber) increased. Caprez et al. $(1986)^{5}$ cited by Devinder et al. (2012) reported in wheat bran that thermal treatments (boiling, cooking or roasting) originate an increase of total fiber that is not due to new synthesis, but rather to the formation of fiber-protein complexes that are resistant to heating and are quantified as dietary fiber.

\subsection{Total polyphenols, total flavonoids and biological activities changes}

While studying the phytochemical characteristics (TPP, TFL) and the antioxidant activities of the spices aqueous extracts, a significant $(p<0.05)$ difference between raw and roasted spices was registered. The results obtained for raw $T$. tetraptera aqueous extracts are in the range of those already published by Darfour et al. (2014) concerning TPP content. The antioxidant activities were investigated and compared, and the results revealed that the spices possess antioxidant activities. The effective scavenging of free radicals exhibited by the spices based on the results obtained from DPPH, lipid peroxide (LP) formation and metalchelating ability (FRAP and TAC) could be attributed to the synergistic effect and significant contributions of many phytochemicals, including polyphenols. High Performance Liquid Chromatography in previous studies (Irondi et al., 2016; Sokamte et al., 2019) has revealed the presence of phenolic acids, flavonoids, alkaloids as major components in both spices. The fruit of T. tetraptera reveals the presence of quercetin, rutin, gallic acid, chlorogenic acid, caffeic acid, apigenin, luteolin, catechin, eugenol, syringic acid, ellagic acid (Irondi et al., 2016; Sokamte et al., 2019) while eugenol, quercetin, epicatechin, ferrulic acid, t-cinnamic acid are the main component of $A$. citratum fruits.

The phenolic compounds in plants mainly act as primary antioxidants and have high redox potentials, which allow them to act as reducing agents, hydrogen donors, singlet oxygen quenchers (Croft, 2016) and metal chelators. The results of this study showed that heat-treated $T$. tetraptera and the formulation contain the highest phenolic content, which correlated with the highest antioxidant potentials. This finding has

${ }^{5}$ Caprez A., Arrigoni E., Amado R. \& Neucom H., 1986. Influence of different types of thermal treatment on the chemical composition and physical properties of wheat bran. J. Cereal Sci., 4, 233-239, doi.org/10.1016/s0733-5210(86)80025-x already been reported by Joel et al. (2017), Sokamte et al. (2019) and Saague et al. (2019). Several studies on spices have been reported in parallel with this finding (Khatun et al., 2006; Raj \& Arulmozhi, 2013). In fact, the raw extracts of spices such as clove (S. aromaticum), cinnamon (Cinnamomum aromaticum) and black pepper (Piper nigrum L.) have shown an improvement in TPP, TFL and in the total antioxidant activity after heat treatment. On the contrary, Nikousaleh \& Prakash (2008) have noticed a decrease on the total antioxidant activity of heattreated black pepper (P. nigrum) and cumin (Cuminum cyminum L.) by heating in the microwave. Kweon et al. $(2017)^{6}$ cited by Wojtowicz et al. (2017) believe that the neoformation of new compounds (furans, pyrroles) according to İzli (2017) and molecular changes explain differences observed before and after heat treatment. Therefore, the registered results can be explained by the degradation of complex phenolic tannins, and the enzymatic or non-enzymatic oxidation process leads to supplementary content of phenolic compounds. Then, temperature would improve the antioxidant potential of foods (spices, vegetables, fruits) by stimulating the antioxidant properties of the available natural compounds or by the neoformation of compounds. The results obtained concerning TPP and TFL are not different than those highlighted by Nwaichi \& Anyanwu (2013), who heated T. tetraptera fruits at $100^{\circ} \mathrm{C}$; Vankar et al. (2006) who heat-treated ginger (Z. officinale) and turmeric (C. longa); Boateng et al. (2008) who thermally treated beans (Phaseolus spp.), and Mastura et al. (2016) who found that cooking causes a significant increase in TPP and TFL content and the total antioxidant activity of a formulation of three spices (onions, chilli, pepper) at 5\% level.

According to the changes in antioxidant activities, the outcomes obtained for heat-treated T.tetraptera and mixed extracts are probably due to their high content of TPP, as reported earlier. Many studies showed that the antioxidant activities of plant extracts are correlated with total phenolic compounds rather than with any individual phenolic compound (da Silva et al., 2019). All of the antioxidant activities are positively and strongly (more than 90\%) correlated with TPP and TFL contents, meaning that most of the observed effects are due to phenolic compounds. Previous studies (Saague et al., 2019; Sokamte et al., 2019) drew the same conclusions for the two plant species extracts. The increase in antioxidant activity may also be indicative that the neoformation of new antioxidant compounds after heat treatment is

\footnotetext{
$\overline{{ }^{6} \text { Kweon M.H., Hwang H.J. \& Sung H.C., 2001 . Identification }}$ and antioxidant activity of novel chlorogenic acid derivatives from bamboo (Phyllostachys edulis). J. Agric. Food Chem., 49, 4646-4655, doi.org/10.1021/jf010514x
} 
Eyenga M., Youovop J.F., Ngondi J.L. et al.

more important than the degradation of antioxidant compounds by heat. Raj \& Arulmozhi (2013) also stated that total polyphenols naturally form complexes with polysaccharides and proteins in food matrices. Under the effect of temperature and the surrounding factors, the hydrolysis reactions occur, thus favoring the dissolution of total polyphenols and consequently improving the antioxidant activity of the extracts. In fact, temperature denatures proteins and hydrolyses starch, thus breaking the weak bonds of the complex formed between polyphenols and these polymers. Nwaichi \& Anyanwu (2013) have shown that there is an increase in the antioxidant activity and the TFL content of T. tetraptera extracts by about $17 \%$ after heat treatment (water bath at $100{ }^{\circ} \mathrm{C}$ for $90 \mathrm{~min}$ ). Changes in the antioxidant activities of Piper guineense Schumach. \& Thonn. and Xylopia aethiopica (Dunal) A.Rich. (two nonwood forest products used as spices) aqueous extracts were also noticed by the same authors. Similar observations were made for six varieties of onions by Sharma et al. (2015), who reported that the content of TFL in red onions increased from 9.34 to $9.70 \mu \mathrm{mol} \cdot \mathrm{g}^{-1}$ $\mathrm{dw}$ when exposed to $120^{\circ} \mathrm{C}$ for $30 \mathrm{~min}$. This effect is even more beneficial since it is reported that most flavonoids inhibit enzymatic and non-enzymatic lipid peroxidation. In fact, there is a significant increase in the antioxidant activities of extracts, suggesting that the heat treatment can have a beneficial effect on the biological activity of the spice constituents.

\section{CONCLUSIONS}

It can be stated that the two spices studied are a good source of nutrients (total sugars, fat, protein, fiber and phenolic compounds) and that applying a heat treatment $\left(140{ }^{\circ} \mathrm{C} / 10 \mathrm{~min} ; \quad 180{ }^{\circ} \mathrm{C} / 20 \mathrm{~min}\right.$ and $150{ }^{\circ} \mathrm{C} / 12 \mathrm{~min}$ respectively for T.tetraptera, A.citratum and the formulation) significantly decreases the dry matter, fat contents and increases the raw fiber, total sugar and phenolic compounds contents. The tests also reveal a strong positive correlation between the total polyphenol content and the total flavonoid content in both spices, irrespective of the heat treatment. Average positive correlations were also noted between total polyphenols, total flavonoids and the in vitro antioxidant activities studied. Then, to improve the release of polyphenol compounds during extraction, spices can be heated and the roasting parameters should be controlled. Nevertheless, stress due to heat treatment remains a major concern in food matrices because of the impact on the nutritional, organoleptic qualities of food and the dangers for the consumer. Therefore, the heat treatment must be optimized according to the objectives pursued. Further studies testing the organoleptic characteristics and non-nutritional content of the spices, as well as the volatile constituents before and after heat treatment, can improve the results of these previous investigations.

\section{Bibliography}

Aboaba S.A. et al., 2009. Essential oil composition, antibacterial activity and toxicity of the leaves of Tetrapleura tetraptera (Schum. \& Thonn.) Taubert from Nigeria. Nat. Prod. Commun., 4, 287-290, doi. org/10.1177/1934578x0900400225

Ahmmed L., Islam M.N. \& Islam M.S., 2015. A quantitative estimation of the amount of sugar in fruits jam available in Bangladesh. Sci. J. Anal. Chem., 3, 52-55, doi. org/10.11648/j.sjac.20150305.12

Ain B.U.H. et al., 2019. Modification of barley dietary fiber through thermal treatments. Food Sci. Nutr., 7(5), 18161820, doi.org/10.1002/fsn3.1026

Alara O.R., Abdurahman N.H. \& Olalere O.A., 2017. Ethanolic extraction of flavonoids, phenolics and antioxidants from Vernonia amygdalina leaf using twolevel factorial design. J. King Saud Univ. Sci., 32(1), 7-16, doi.org/10.1016/j.jksus.2017.08.001

AOAC, 1990. Official methods of analysis of association of official analytical chemists. $15^{\text {th }}$ ed. Arlington, VA, USA: AOAC, 1-50.

AOAC, 2000. Official methods of analysis. $17^{\text {th }}$ ed. Rockville, MD, USA: AOAC.

Bastías J.M. et al., 2017. Determining the effect of different cooking methods on the nutritional composition of salmon (Salmo salar) and chilean jack mackerel (Trachurus murphyi) fillets. PLoS ONE, 12(7), e0180993, doi.org/10.1371/journal.pone.0180993

Boateng J., Verghese M., Walker L.T. \& Ogutu S., 2008. Effect of processing on antioxidant contents in selected dry beans (Phaseolus spp. L.). LWT - Food Sci. Technol., 41(9), 1541-1547, doi.org/10.1016/j. lwt.2007.11.025

Croft K.D., 2016. Dietary polyphenols: antioxidants or not? Arch. Biochem. Biophys., 595, 120-124, doi. org/10.1016/j.abb.2015.11.014

da Silva K.M. et al., 2019. Effect of fruit ripening on bioactive compounds and antioxidant capacity of apple beverages. Food Sci. Technol., 39(2), 294-300, doi. org/10.1590/fst. 25317

Darfour B. et al., 2014. Gamma irradiation of Tetrapleura tetraptera fruits as a post-harvest technique and its subsequent effect on some phytochemicals, free scavenging activity and physicochemical properties. Radiat. Phys. Chem., 102, 153-158, doi.org/10.1016/j. radphyschem.2014.05.003

Devinder D.,Mona M.,Rajput H.\&Patil R.T.,2012.Dietary fibre in foods: a review. J. Food Sci. Technol., 49(3), 255-266, doi.org/10.1007\%2Fs13197-011-0365-5

Djikeng F.T. et al., 2018. Effect of traditional and oven roasting on the physicochemical properties of fermented 
cocoa beans. Heliyon, 4(2), 3-17, doi.org/10.1016/j. heliyon.2018.e00533

Domiszewski Z., Bienkiewicz G. \& Plust D., 2011. Effects of different heat treatments on lipid quality of striped catfish (Pangasius hypophthalmus). Acta Scientiarum Polonorum Technol. Aliment., 10(3), 359-373.

Eyog-Matig O., Ndoye O., Kengue J. \& Awono A., 2006. Les fruitiers forestiers comestibles du Cameroun. Cotonou, Bénin : IPGRI.

Hildebrant K.L., 2016. The guide to $\mathrm{pH}$ measurement in food and drink. Our daily brine - Version 1.0, https:// ourdailybrine.com/wp-content/uploads/odb_guide_to_ ph_measurement_in_food_v1-0.pdf, (22/06/2020).

Horváthová J., Suhaj M. \& Šimko P., 2007. Effect of thermal treatment and storage on antioxidant activity of some spices. J. Food Nutr. Res. (Slovak Republic), 46(1), 20-27.

Immaculate Bites, 2013. Mbongo Tchobi (African Spicy Black Stew), https://www.africanbites.com/mbongotchobi-african-spicy-black-stew/, (18/10/2019).

Irondi E.A. et al., 2016. Phenolics extract of Tetrapleura tetraptera fruits inhibits xanthine oxidase and $\mathrm{Fe}^{2+}$ induced lipid peroxidation in the kidney, liver, and lung tissues of rats in vitro. Food Sci. Hum. Wellness, 5, 17 23, doi.org/10.1016/j.fshw.2015.11.001

İzli G., 2017. Total phenolic, antioxidant capacity, color and drying characteristics of date fruit dried with different methods. Food Sci. Technol., 37(1), 139-147, doi.org/10.1590/1678-457x.14516

Joel J.S. et al., 2017. Comparative antioxidant capacity of aqueous and ethanol fruit extracts of Tetrapleura tetraptera. J. Biol. Sci., 17(4), 185-193, doi. org/10.3923/jbs.2017.185.193

Jongen W.M.F., 2002. Fruit and vegetable processing: improving quality. Cambridge, UK: Woodhead Publishing, CRC Press, doi. org/10.1201/9781439823187

Jung S. et al., 2003. Comparison of Kjeldahl and Dumas methods for determining protein contents of soybean products. J. Am. Oil Chem. Soc., 80(12), 1169-1173, doi.org/10.1007/s11746-003-0837-3

Kim J.-S., 2012. Comparison of antioxidant properties of water and ethanol extracts obtained from dried boxthorn (Lycium chinensis) fruit. Food Nutr. Sci., 3(9), 13071320, doi.org/10.4236/fns.2012.39173

Lemos M.R.B, Machado de Almeida Siqueira E.,Fernandez Arruda S. \& Zambiazi R.C., 2012. The effect of roasting on the phenolic compounds and antioxidant potential of baru nuts (Dipteryx alata Vog). Food Res. Int., 48(2), 592-597, doi.org/10.1016/j.foodres.2012.05.027

Maskat M.Y. \& Tan S.M., 2011. Effect of heat treatment on the physicochemical properties of Mengkudu (Morinda citrifolia) extract. Int. Food Res. J., 18(3), 1007-1011.

Mastura H.Y., Hasnah H. \& Yap Y.T., 2016. Total phenolic content and antioxidant capacities of instant mix spices cooking pastes. Int. Food Res. J., 24(1), 68-74.
Meffo S.C.D. et al., 2019. Essential oils from seeds of Aframomum citratum (C.Pereira) K.Schum, Aframomum daniellii (Hook. F.) K.Schum, Piper capense (Lin. F) and Monodora myristica (Gaertn.) Dunal NL and their antioxidant capacity in a cosmetic cream. J. Essent. Oil Bear. Plants, 22, 324-334, doi.or g/10.1080/0972060x.2019.1612282

Mohammad M. et al., 2019. Kinetics of temperature effect on antioxidant activity, phenolic compounds and color of Iranian jujube honey. Heliyon, 5(1), e01129, doi. org/10.1016/j.heliyon.2019.e01129

Moukette B.M. et al., 2015. In vitro ion chelating, antioxidative mechanism of extracts from fruits and barks of Tetrapleura tetraptera and their protective effects against Fenton mediated toxicity of metal ions on liver homogenates. Evidence-Based Complementary Altern.Med., 2015, 1-14, doi.org/10.1155/2015/423689

Mullin W.J. \& Smith J.M., 1991. Dietary fiber in raw and cooked potatoes. J. Food Compos. Anal., 4(2), 100106, doi.org/10.1016/0889-1575(91)90003-o

Neelam Y. et al., 2018. Effect of thermal and non-thermal processing on antioxidant potential of cowpea seeds. Int . J. Food Prop., 21(1), 437-451, doi.org/10.1016/08891575(91)90003-o

Ngassoum M., Jirovetz L. \& Buchbauer G., 2001. SPME/ GC/MS analysis of headspace aroma compounds of the Cameroonian fruit Tetrapleura tetraptera (Thonn.) Taub. Eur. Food Res. Technol., 213, 18-21, doi. org/10.1007/s002170100330.

Ngo Samnick A.F., Ngo Mbanga M.E. \& Ngo Samnick E.L., 2016. Aux 1000 saveurs de Tayap. CreateSpace Independant Publishing Platform.

Nguyen T.T.K., Laosinwattana C., Teerarak M. \& Pilasombut K., 2017. Potential antioxidant and lipid peroxidation inhibition of Phyllanthus acidus leaf extract in minced pork. Asian-Australas. J. Anim. Sci., 30(9), 1323-1331, doi.org/10.5713/ajas.17.0036

Nikousaleh A. \& Prakash J., 2008. Effect of dry heat treatment of six spices on antioxidant activity of their water extracts. Food, 2(2), 139-144.

Nikousaleh A.\& Prakash J.,2016.Antioxidant components and properties of dry heat-treated clove in different extraction solvents. J. Food Sci. Technol., 53(4), 19932000, doi.org/10.1007/s13197-015-2113-8

Njike Nya P., 1998. L'art culinaire camerounais. Paris : L'Harmattan, 1-168.

Nwaichi E.O.\& Anyanwu P., 2013. Effect of heat treatment on the antioxidant properties of Tetrapleura tetraptera, Xylopia ethiopica and Piper guineense. J. Med. Res. Dev. (JMRD), 2(3), 59-63. Nwinuka N.M., Ibeh G.O. \& Ekeke G.I., 2005. Proximate composition and levels of some toxicants in four commonly consumed spices. J. Appl. Sci. Environ. Manage., 9(1), 150-155.

Polovka M. \& Suhaj M., 2010. The effect of irradiation and heat treatment on composition and antioxidant properties of culinary herbs and spices - a 
review. Food Rev. Int., 26(2), 138-161, doi. org/10.1080/87559121003590227

Prieto P.,Pineda M.\&Aguilar M., 1999. Spectrophotometric quantitation of antioxidant capacity through the formation of a Phosphomolybdenum complex: specific application to the determination of vitamin E. Anal. Biochem., 269(2), 337-341, doi.org/10.1006/abio.1999.4019

Raj N. \& Arulmozhi K., 2013. Efficacy of heat treatment on the in vitro antioxidant activity of selected spices. Int. J. Curr. Microbiol. Appl. Sci., 11, 13-18.

Saague P.W.K. et al., 2019. Phenolic compounds from waterethanol extracts of Tetrapleura tetraptera produced in Cameroon, as potential protectors against in vivo $\mathrm{CCl} 4$ induced liver injuries. Sci. World J., 2019, 1-10, doi. org/10.1155/2019/5236851.

Sharma K. et al., 2015. Temperature-dependent studies on the total phenolic, flavonoids, antioxidant activities, and sugar content in six onion varieties. J. Food Drug Anal., 23(2), 243-252, doi.org/10.1016/j.jfda.2014.10.005

Silarova P., Boulekbache-Makhlouf L., Pellati F. \& Ceslova L., 2019. Monitoring of chlorogenic acid and antioxidant capacity of Solanum melongena L. (eggplant) under different heat and storage treatments. Antioxidants (Basel), 8(7), 234, doi.org/10.3390/antiox8070234

Sneyd L., 2013. Wild food, prices, diets and development: sustainability and food security in urban Cameroon. Sustainability, 5(11), 4728-4759, doi.org/10.3390/ su5114728

Sokamte T.A., Mbougueng P.D., $\quad$ Tatsadjieu N.L. \& Sachindra N.M., 2019. Phenolic compounds characterization and antioxidant activities of selected spices from Cameroon. South Afr. J. Bot., 121, 7-15, doi. org/10.1016/j.sajb.2018.10.016

Tumuluru J.S., 2016. Effect of deep drying and torrefaction temperature on proximate, ultimate composition, and heating value of 2-mm lodgepole pine (Pinus contorta) Grind. Bioengineering (Basel), 3(16), 16, doi. org/10.3390/bioengineering3020016

Uyoh E.A., Ita E.E. \& Nwofia G.E., 2013. Evaluation of the chemical composition of Tetrapleura tetraptera (Schum and Thonn.) Taub. accessions from Cross River State, Nigeria. Int. J. Med. Arom. Plants, 3, 386-394.

Vankar P.S., Shanker R., Srivastava J. \& Vandana T., 2006. Change in antioxidant activity of spices turmeric and ginger on heat treatment. Electron. J. Environ. Agric. Food Chem., 5(2), 1313-1317.

Wojtowicz E., Krupska A. \& Zawirska-Wojtasiak R., 2017. Antioxidant activity and free radicals of roasted herbal materials. Herba Pol., 63(2), 34-41, doi.org/10.1515/ hepo-2017-0011

Woo K.S. et al., 2015. Characteristics of the thermal degradation of glucose and maltose solutions. Preventive Nutr. Food Sci., 20(2), 102-109, doi.org/10.3746/ pnf.2015.20.2.102

Yashin A., Yashin Y., Xia X. \& Nemzer B., 2017. Antioxidant activity of spices and their impact on human health: a review. Antioxidants (Basel), 6(3), 70, doi. org/10.3390/antiox6030070

(53 ref.) 